\title{
The Non-Sustainability of Rwanda's Economic Miracle
}

\author{
George B. N. Ayittey ${ }^{1}$ \\ ${ }^{1}$ Free Africa Foundation, Washington DC, USA \\ Correspondence: George B. N. Ayittey, Free Africa Foundation, Washington DC, USA. Tel: 1-703-475-2527. \\ E-mail: ayittey@gmail.com
}

Received: March 30, 2017

Accepted: April 28, 2017 Online Published: May 29, 2017

doi:10.5539/jms.v7n2p88

URL: http://doi.org/10.5539/jms.v7n2p88

\begin{abstract}
Emerging out of the horrific spasm of genocide that claimed more than 800,000 of the minority Tutsi ethnic group in 1994, Rwanda has chalked up some spectacular economic performance. Its rate of economic growth has averaged 8\% since 2001 and it is among the fastest growing economies in East Africa. Poverty rates have been halved and Rwanda is one of the very few African countries that was able to achieve the United Nations' Millennium Development Goals (MDGs). It also has the highest representation of women in Parliament.

This paper, however, argues that impressive though Rwanda's economic performance might be, it is not sustainable. First, it is heavily dependent upon foreign aid, making it vulnerable to fluctuations in aid. Second, the Asian Tiger economic model Rwanda copied from Singapore-development under authoritarianism-has failed miserably in postcolonial Africa. No dictator - civilian, military nor rebel—has brought lasting prosperity to any African country. Third, the other types of reform Rwanda needs to sustain its economic achievement-intellectual, political, constitutional and institutional reforms - are petulantly missing. How these reforms are sequenced is also critically important. Focusing only on economic liberalization to the detriment of the other reforms amounts to putting the cart before the horse. Finally and most disconcerting of all, in his understandable zeal to prevent another genocide, Rwanda's President Paul Kagame is unwittingly re-creating the very conditions that led to the 1994 genocide - a supreme irony.
\end{abstract}

Keywords: Botswana, Burundi, democracy, economic miracle, ethnic partitioning, genocide, intellectual freedom, Kagame, non-sustainability, Rwanda

\section{Introduction}

Africa is a continent teeming with absurd contradictions and brutal ironies. One meretricious aspect of the struggle against the abominable system of apartheid in South Africa in the late 1980s was that the black African leaders leading the campaign to demand one man, one vote for blacks in South Africa-which they should have - did not give the same political rights to their own people living in their own black African countries. In 1990, only four African countries-Botswana, Gambia, Mauritius and Senegal-were democratic. In January 2017, only 16 out of 54 countries were democratic - Benin, Botswana, Cape Verde Islands, Gambia, Ghana, Kenya, Malawi, Mauritius, Mozambique, Namibia, Nigeria, Sao Tome \& Principe, Senegal, South Africa, Tanzania and Zambia. (Note 1) Even more perfidious was that equally heinous de facto apartheid regimes pervaded the rest of Africa. Under South Africa's obnoxious system, the white minority captured political and economic power and excluded the black majority from participation in government and the spoils system. But in Sudan and Mauritania, Arabs held power and excluded blacks (Arab apartheid); in Rwanda and Burundi, the Hutus and Tutsis alternated usurping power; in Nigeria the Hausa-Fulani ran the government (tribal apartheid); Togo, Zaire, and Uganda were overtaken by the military (stratocracy); and Angola, Cote d'Ivoire, Mozambique, Kenya, and Tanzania were run by one political party (one-party state).

Regardless of the ethnicity, skin color, political party or religion of the oppressor, the politics of exclusion has been the root cause of Africa's chronic crises of political instability, civil strife, wars, and chaos. Since 1960, more than 40 wars have been waged in Africa, the vast majority of which were intra-state in origin. Nearly all the civil wars and rebel insurgencies were started by politically excluded or marginalized groups. These wars uprooted people and created massive refugee problems. (Note 2) The toll on Africa's agriculture has been particularly devastating since most of the refugees have been women and children, who constitute more than $60 \%$ of Africa's peasant farmers. Africa used to feed itself back in the 1950s but not anymore. 
As former U.N. Secretary-General, Kofi Annan, noted in his UN April 16, 1998 Report to the Security Council:

"The nature of political power in many African States, together with real or perceived consequences of capturing and maintaining power, is a key source of conflicts across the African continent. It is frequently the case that political victory assumes a "winner-takes-all" form with respect to wealth and resources, patronage, and the prestige and prerogatives of office. A communal sense of advantage or disadvantage is often closely linked to this phenomenon, which is heightened in many cases by reliance on centralized and highly personalized forms of governance... This situation is exacerbated when, as is often the case in Africa, the State is the major provider of employment and political parties are either regionally or ethnically based. In such circumstances, the multi-ethnic character of most African States makes conflict even more likely, leading to an often violent politicization of ethnicity." (UN, 1998, p. 3).

One of the "Iron Laws" of African mis-governance this author enunciated is that the destruction of an African country always begins with a dispute over the electoral process or transfer of power (Ayittey, 1211 (2011), p. 241). So many countries-from Burundi, Ivory Coast, Liberia, Libya, Rwanda to Sierra Leone and Somalia - would have been saved had their leaders been willing to relinquish or share political power (the politics of inclusion). This Iron Law was in full play in both Burundi and Rwanda before the 1994 genocide. A brief history of both countries is necessary as events in one country cannot be well understood without the other.

Both countries are populated by two ethnic groups - the minority Tutsis, who constitute less than 15 percent of the populations in both countries, and the majority Hutus. (Note 3) The tall Tutsis (also called Watutsis) are pastoralists who originally migrated southward from Ethiopia and established their sovereignty over the native Hutus, who are smaller in stature and mostly farmers. The Tutsis enforced overlordship and segregation through superior wealth (measured in cattle), superior military organization, and control over the allocation of land. The Hutu peasantry were held to an inferior status and forced to labor for the Tutsis as servants and tillers for free. (Note 4) Tutsi simply means "rich in cattle", while Hutu means "servant", and this partly fueled Hutu resentment and anger against past social injustices.

In Rwanda, the master-client relationship was accentuated at first by German colonialists (1890-1916) and after they lost WW1 by Belgian colonial administrators (1916-1962). The Tutsis were accorded authority and power over the country, given administrative jobs and a monopoly in the educational system set up by Catholic missionaries. The Hutu peasantry, held in centuries of serfdom and subjugation by the minority Tutsis, became increasingly resentful during colonial rule. On July 25, 1959, they rose in rebellion and overthrew their Tutsi overlords, killing an estimated 100,000 Tutsis. A shocked Belgian colonial government hurriedly and belatedly introduced political reform. A 1961 U.N. supervised-referendum adopted a republican constitution, and parliamentary elections brought the Hutu majority party, Parmehutu, to power. Independence was attained on July 1, 1962, but thereafter the Tutsis launched sporadic guerrilla attacks to regain their old hegemony. One such expedition in 1963 by Tutsi guerrillas, unwisely backed by China, resulted in the massacre of more than 20,000 Hutus.

The Hutu-controlled government grew increasingly paranoid, despotic and corrupt. In 1990 another rebel Tutsi group, demanding democratic pluralism, led an invasion into Rwanda from neighboring Uganda. Fighting and killings continued intermittently in and around the capital, Kigali, despite the presence of 2,500 U.N. peacekeeping troops drawn from 24 countries. Tutsi insurrections failed to win political power and efforts to reach an accord between Tutsi rebels and the Hutu-dominated government led to an impasse in 1993.

Naturally, the Government of Rwanda disputes this precolonial narrative:

"Since the 11th century, Rwanda existed as a nation founded on a common history of its people, shared values, a single language and culture, extending well beyond the current borders of the country. The unity of the Rwandan nation was also based on the clan groups and common rites with no discrimination based on ethnicity.

The colonial power, based on an ideology of racial superiority and in collaboration with some religious organizations, exploited the subtle social differences and institutionalized discrimination. These actions distorted the harmonious social structure, creating a false ethnic division with disastrous consequences' (Republic, 2012, p. 9)

Burundi was the sister German colony to Rwanda, administered jointly by the Germans as Ruanda-Urundi. The German, and subsequent Belgian, colonial policy of indirect rule through chiefs gave strong powers to Tutsi overlords, exacerbated social tensions in Burundi just as in Rwanda. The assassination of Louis Rwagasore, a Tutsi and a nationalist leader, on Oct 13, 1961, by an European, just months before independence in 1962, opened up deep divisions and suspicions within the Tutsi elite, which led to their defeat in the 1964 
parliamentary elections. But the then Tutsi head of state, MwamiMwambutsa, refused to name a Hutu prime minister, whereupon the Hutu military and political elite staged an abortive coup in October 1965. A brutal purge of Hutus from the army and the bureaucracy followed, leading to a Hutu uprising in April 1972 that resulted in the deaths of about 1,000 Tutsis. Thereupon the ruling Tutsi aristocracy decided to eliminate the "Hutu threat" by killing every Hutu with education, a government job, or money. Within three months, more than 200,000 Hutus had been slain.

The Tutsi minority maintained its monopoly on political power and instituted a bizarre passbook system — akin to the ignominious South African apartheid pass system - to exclude the majority Hutus from key government and army positions. In August 1988, following another abortive coup attempt, the Tutsi-run military government under General Pierre Buyoya massacred an estimated 20,000 Hutus. "U.N. officials at refugee camps near the border with Rwanda told of soldiers chasing, machine-gunning, and bayoneting fleeing Hutus. The scale and barbarity of the atrocities shocked many Western aid officials." (Note 5)

The carnage was repeated in 1993, following Burundi's first multiparty elections, which were won by the Hutus. A Hutu civilian president, Meldior Ndadaye, was sworn in as president. Within three months, the Tutsi-dominated military overthrew the Hutu civilian government and bayoneted its president, Ndadaye, to death, instigating a horrific tribal massacre that claimed over 100,000 Hutu lives and sent more than 500,000 refugees streaming into Rwanda, Tanzania, and Zaire (now Congo DR). His death also convinced Hutu extremists in Rwanda of the need to act.

On April 4, 1994, President Habyarimana of Rwanda traveled with Burundi's president, Cyprien Ntaryamira, to Dar es Salaam, Tanzania, where they met other African leaders in an attempt to end years of ethnic warfare in their countries. On their return, from Tanzania, on April 6, the two presidents were killed in an apparent rocket attack on their plane. The rockets were fired from the immediate vicinity of the Kigali airport, an area controlled by the Rwandan army. Though no one claimed responsibility the death of Habyarimana provided extremists within the ruling group with the long-sought pretext for wiping out the Tutsi.

Following the death of President Habyarimana. The elite Presidential Guard sprang into action. Hutu hard-liners turned on Hutu moderates, who favored negotiations. Groups in the army, cabinet, and civil service battled one another. Rwanda's interim prime minister, Agathe Uwilingiyimana, and three cabinet ministers - all Hutus and of the same tribe as the soldiers-were brutally killed. (Note 6) Taking advantage of the confusion, people began settling old tribal scores. The melee quickly degenerated into a free-for-all. (Note 7) About 800,000 Tutsis were slain in the orgy of violence. With the Presidential Guard and army destroyed, the small Tutsi rebel battalion under Paul Kagame, sailed into the capital, Kigali, meeting little resistance. Fearing reprisals, about 1.1 million Hutu refugees fled across the border into French-speaking Zaire, now Congo DR. Paul Kagame is widely hailed and credited for saving the minority Tutsi ethnic group from extinction. Since that horrific massacre, he has engineered a remarkable economic recovery.

Given this background, several issues bubble up to the surface. First of all, could the genocide have been prevented and what are the chances that it may re-occur in the future? Dozens of civil wars have been waged in postcolonial Africa, leaving a horrendous human toll-over 6 million in Congo DR, more than 4 million in Sudan, over 3 million In the Biafra War in Nigeria, to name a few. Can these countries recover from brutal civil wars and, if so, how many years does it take? Rwanda's experience shows that it may take a generation. Furthermore, postcolonial Africa has been in dire need of economic success stories. Is Rwanda's economic success sustainable and can it be replicated elsewhere in Africa? Is there a more suitable economic model for African countries?

Section 2 begins with a literature review of these issues. Section 3 discusses the remarkable economic progress achieved by Rwanda since the genocide. The purpose of this paper is to assess the sustainability of that economic achievement, which is undertaken in Section 4. It argues that Rwanda's economic miracle-admirable though it may be - is not sustainable because the model is copied from abroad. This was the modus operandi of most postcolonial African leaders, who borrowed or copied a slew of foreign systems and paraphernalia to impose on their people. Most of these imported systems failed disastrously. The more appropriate economic model that Rwanda should have adopted can be found in Botswana. With additional reforms - in particular, intellectual and democratic freedoms - Rwanda can make its economic achievements more sustainable. But the Tutsi minority is terrified of relinquishing power and embracing democracy - a veritable dilemma. The final Section 5 reluctantly concludes that the status quo is untenable and Rwanda may have to bite the bullet and establish real democracy or submit to ethnic partitioning-Tutsi in Rwanda and Hutu in Burundi. 


\section{Area Studied and Literature Review}

Africa's postcolonial economic performance has been dismal. Despite immense mineral wealth and massive inflows of foreign aid — over $\$ 600$ billion since 1960 - the continent has barely been able to keep its head above water, perennially wracked by one crisis after another. Half a century after independence in the 1960s, fewer than 5 of the 54 African countries are doing well economically. Among them may be mentioned Botswana, Ethiopia, Mauritius, Rwanda and Uganda. Such economic stars have appeared in the past only to fizzle out and implode.

Rwanda has done remarkably well economically, emerging out of a horrific genocide in 1994, which targeted minority Tutsi ethnic group. But as shown in the introduction, the issue is not just genocide of the Tutsi. It is far more complex, centering on the politics of exclusion. Since the 1950s, both ethnic groups have periodically launched brutal pogroms and reprisal pogroms against one another. The West has generally been criticized - and in this author's view, unfairly - for not intervening to stop the genocide. In fact, at its July 2000 Summit in Lome, Togo, the erstwhile Organization of African Unity (OAU) demanded a Marshall Aid type of reparations for Rwanda from the West for failing to stop the genocide - as if the OAU or Africa leaders lifted a finger to stop the carnage. More disturbing after several decades of bloodletting on both sides, the fundamental cause of the deadly violence-political power monopolization and exclusion-remains dangerously unresolved in both countries. It may not be idle persiflage to speculate that future pogroms may be inevitable.

Rwanda attracted world attention following the traumatic genocide in 1994. Prior to that catastrophic event, little has been written about the country and its sister country, Burundi. Melvern (2013) provides a robust historical background to the genocide as well as a scathing indictment of Western nations - in particular, the US - for doing nothing to stop it. Publication by the Government of Rwanda, for example, Vision 2020 are invaluable in providing insights to the challenges and frustrations experienced by the people.

Since this paper discusses the non-sustainability of Rwanda's economic achievement, there is much reliance on economic data and analysis by IMF fact sheets or newsletters, publications by the World Bank $(2015,2016)$ and the World Economic Forum (2016) - all of which attest to Rwanda's spectacular economic progress. There is general consensus about this progress - a conclusion reached elsewhere by Ansoms (2005) and Crisafulli \& Redmond (2012). Naturally, there are skeptics. UNDP (2011) believes the Rwandan government vision of achieving middle income status by 2020 is overly optimistic. Current levels of private investment-both domestic and foreign - as a percentage of GDP do not warrant such optimism — a view supported by World Bank. Nor can Rwanda indefinitely rely on large inflows of foreign aid as the World Bank (2016) makes clear.

The unique contribution of this paper is the employment of noneconomic factors-often ignored in the literature - not only to buttress the same conclusion of non-sustainability but also to warn that Rwanda's miraculous economic achievements may unravel if additional reforms are not implemented. These reforms are intellectual freedom, political reform, constitutional reform and institutional reform. Of critical importance is how these reforms are sequenced. This topic has not been discussed in the literature, much less in relation to postcolonial African experience. As Ayittey (2011) argues, Africa's postcolonial experience suggests that economic liberalization alone is not enough to engineer prosperity. Democracy is vital to sustain it. In 1989, Ivory Coast was hailed as an economic miracle but collapsed into civil wars in 2005 and 2010 for lack of democracy. Similarly, Madagascar was an economic success story in 2003 but was plunged into political turmoil and instability for ten years. Rwanda may suffer the same fate as it is not democratic.

Even then, the achievements of Rwanda have not been without controversy. The country has been accused of plundering the mineral wealth of Congo DR (UN, 2001) and Montague (2002). The activities of the Rwandan government in neighboring countries have also raised concern in international circles. The UN (2012), for example, has condemned the Rwandan government support of M23 rebels in Congo DR.

The next section discusses Rwanda's economic achievements.

\section{Spectacular Economic Achievement}

Emerging out of the horrific 1994 genocide, Rwanda's economy has made stupendous recovery. People are generally living healthier and wealthier lives. The World Economic Forum (2016) provided this snapshot of Rwanda's economy in January 2017:

One of the fastest growing economies in Central Africa, Rwanda notched up GDP growth of around 8\% per year between 2001 and 2014 . 
The IMF expects the economy to slow down this year [2017] and pick up in 2018, forecasting around 6\% growth in 2018 compared with $6.9 \%$ last year. The IMF said Rwanda's growth in 2015 was driven by construction, services, agriculture and manufacturing, but mining exports have slowed.

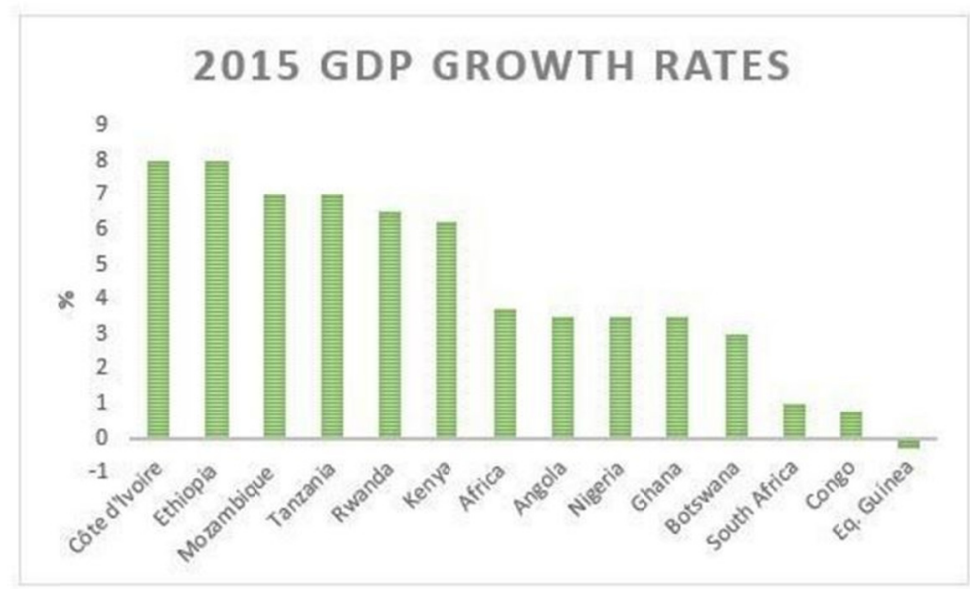

Source: World Economic Forum (2016).

Rwanda reduced the percentage of people living below the poverty line from $57 \%$ in 2005 to $45 \%$ in 2010 . Despite this, $63 \%$ of the population still live in extreme poverty, defined by the World Bank as less than $\$ 1.25$ a day. Nonetheless, Rwanda is one of the few African countries that was able to meet most of the Millennium Development Goals (MDGs) (Ayittey, 2015). World Bank (2016) provided additional details:

"Strong economic growth was accompanied by substantial improvements in living standards, evidenced by a two-thirds drop in child mortality and the attainment of near-universal primary school enrolment. A strong focus on home grown policies and initiatives contributed to a significant improvement in access to services and in human development indicators. The poverty rate dropped further from $44 \%$ in 2011 to $39 \%$ in 2014 while inequality measured by the Gini coefficient reduced from 0.49 in 2011 to 0.45 in 2014."

Life expectancy, literacy, primary school enrolment and spending on healthcare have all improved. Rwanda has also made big strides towards gender equality - almost $64 \%$ of parliamentarians are women, compared to just $22 \%$ worldwide - which has enabled women in the country to make economic advances. Women are now able to own land and girls can inherit from their parents.

\begin{tabular}{lll}
\hline & Country & Women in Parliament (percentage) \\
\hline $\mathbf{1}$ & Rwanda & 63.8 \\
$\mathbf{2}$ & Bolivia & 53.1 \\
$\mathbf{3}$ & Cuba & 48.9 \\
$\mathbf{4}$ & Seychelles & 43.8 \\
$\mathbf{5}$ & Sweden & 43.6 \\
$\mathbf{6}$ & Senegal & 42.7 \\
$\mathbf{7}$ & South Africa & 41.9 \\
$\mathbf{8}$ & Ecuador & 41.6 \\
$\mathbf{9}$ & Finland & 41.5 \\
$\mathbf{1 0}$ & Iceland & 41. \\
\hline
\end{tabular}

Source: World Economic Forum (2016).

Rwanda's long-term development goals were defined in a government-enunciated strategy entitled "Vision 2020", which seeks to transform the country from a low-income agriculture-based economy to a knowledge-based, service-oriented economy with a middle-income country status by 2020 . According to the World Bank (2016),

"In order to achieve these long-term development goals, the Government of Rwanda has formulated a medium-term strategy. The second Economic Development and Poverty Reduction Strategy (EDPRS 2) 
outlines an overarching goal of growth acceleration and poverty reduction through four thematic areas: economic transformation, rural development, productivity and youth employment, and accountable governance. The EDPRS 2 aims to achieve the following goals by 2018: raise gross domestic product (GDP) per capita to $\$ 1,000$; have less than $30 \%$ of the population below the poverty line; and have less than $9 \%$ of the population living in extreme poverty.

These goals build on remarkable development successes over the last decade which include high growth, rapid poverty reduction and, since 2005, reduced inequality. Between 2001 and 2015, real GDP growth averaged about 8\% per annum. Recovering from the 2012 aid shortfall, the economy grew 7\% in 2014 and $7.5 \%$ in 2015 , up from 4.7\% in 2013." (Note 8)

However, the World Bank (2016) is skeptical if Vision 2020 would be attainable. It wrote: "Currently around 83\% of Rwanda's population of 10.5 million live in rural areas and more than $70 \%$ of the population still work in subsistence farming. But the government, led by President Paul Kagame, wants to... transform Rwanda from a low-income agriculture-based economy to a knowledge-based, service-oriented economy with a middle-income status by 2020." It would be a Herculean task to seek to accomplish this feat within four years.

The United Nations Conference on Trade and Development (UNCTAD) was even more blunt. Andrew Mold, acting director of the UN Economic Commission for Africa, quoted UNCTAD as saying "Rwanda will still be least developed by 2025." (Note 9) An earlier report by UNDP (2011) found that,

- The number of Rwandans living in poverty increased from 4.8 million to 5.4 million.

- Inequality has increased: The Gini coefficient increased from 0.47 to 0.51 in 2011 [although this decreased 0.45 in 2014].

\section{Non-Sustainability of Rwanda's Economic Miracle}

Like all economies, Rwanda's also faces its share of problems. With remarkable forthrightness, the government admitted that the economy faced some challenges,

"The economy of Rwanda is currently characterized by internal (budget deficit) and external (Balance of Payments) macroeconomic disequilibria, alongside low savings and investment rates and high unemployment and underemployment. In addition, Rwanda's exports, composed mainly of tea, coffee and minerals - whose prices are subject to fluctuations on the international market - have not been able to cover imports needs" (Republic, 2012, p. 10).

To avoid bankruptcy, Rwanda requested an 18-month standby credit facility (SCF) arrangement with access to about US\$204 million (SDR 144.18 million) or 90 percent of Rwanda's quota and to extend Rwanda's policy support instrument (PSI)-supported program through end-2017 (IMF Press Release No. 16/270). This was approved by the Board on June 8, 2016. Half was disbursed upon approval of the SCF arrangement, and with completion of the first review of the SCF arrangement another US\$48.65 million (SDR 36.045 million) would become available for disbursement. The remaining financing would be considered in two subsequent reviews in 2017. (Note 10)

To be sure, countries borrow from the IMF to overcome temporary economic adversity. However, the problems in Rwanda go much deeper and should not be brushed off perfunctorily because they undermine Rwanda's impressive achievement. There are six major concerns. (Note 11)

\subsection{Foreign Aid Dependency}

Foreign aid to Rwanda increased significantly when the country began rebuilding itself after the genocide. A large chunk of government revenues - 30 to $40 \%$ of the budge - still comes from aid. The World Bank (2016) asserts that Rwanda's economy is vulnerable to fluctuations in foreign aid. Indeed growth fell to $4.7 \%$ in 2013 after some donors withheld aid over allegations in a 2012 UN report that the government was backing M23 rebels in the Democratic Republic of Congo. The World Bank (2015) is skeptical whether Rwanda can maintain high growth rates without foreign aid:

Rwanda's economic resilience will not be achieved without keeping high investment rates. However, the current investment model (high public investment funded by aid) is not likely to be sustainable; given capacity constraints to maintain high public investment and possible decline in aid relative to GDP in the medium-term. Finding alternative sources of development financing is a key determinant of future growth. Development of the financial sector is critical to mobilize both domestic and foreign saving for financing development. 
Western aid to Rwanda has been driven largely out of guilt for negligence in doing something to stop the 1994 genocide. That neglect can be explained by two factors. The first was the aftermath of "Operation Restore Hope" - a UN humanitarian mission to Somalia led by the US, which in December 1992 deployed 25,000 troops. The objective was to secure trade routes so that food could reach the people. However, something went terribly wrong. A firefight erupted between US Rangers and the warlord, Mohamed Aideed and his followers on October 3, 1993. Eighteen Rangers were killed and the body of one dragged through the streets of Mogadishu. (Note 12) On October 7, President Clinton withdrew US troops from Somalia. The United Nations followed suit a year later. Having been burnt in Somalia, there was virtually no Western appetite for another misadventure in Africa when Rwanda imploded in April 1994.

The second was the reluctance on the part of US officials to call the Rwanda genocide what it was - genocide - for fear that it would have automatically triggered a US response, as required by treaties and diplomatic conventions, in particular the 1948 Genocide Convention. (Note 13) Thus, when the Tutsi minority in Rwanda were being slaughtered the horrific event was not called genocide in the US. In fact, Clinton himself admitted, "The international community... must bear its share of responsibility... We did not act quickly enough after the killing began... We did not immediately call these crimes by their rightful name, genocide. Never again must we be shy in the face of the evidence." (Note 14)

Feeling sorry for the negligence and to make amends, Clinton and former UK Prime Minister Tony Blair became strong advocates and raised money for Rwanda. On a trip to Rwanda on April 6, 1998, Clinton apologized to genocide survivors on behalf of the US for not coming to their aid. (Note 15) Speaking to CNBC Meets' Tania Bryer, he admitted that if the U.S. had gone into Rwanda sooner following the start of the 1994 genocide, at least a third or roughly 300,000 lives could have been saved. He explained that the failure of his administration to act was one of the reasons behind the establishment of the Clinton Foundation. It had an enduring impact on me (CNBS, http://www.cnbc.com/id/100546207).

Perhaps it can be argued that President Paul Kagame has overused and overexploited this contrition to commit his own grotesque spate of human rights violations, knowing full well that the West lacks the moral authority to criticize him.

\subsection{Unsuitable Economic Model}

"We want to learn a lot from Singapore that has been very successful, that has turned a lot of challenges historically into a lot of opportunities," Kagame told National Public Radio's correspondent, Frank Langfitt, on September 16, 2012. (Note 16) While Rwanda has done well economically, the Asian Tiger Model - development under authoritarianism - is not one African countries should emulate. This model has never worked in postcolonial Africa. In fact, no dictator - military, civilian nor rebel-has brought lasting prosperity to any African country because the situations of the two continents are vastly different. First, the Asian Tigers have relatively more ethnically homogeneous populations than in Africa. Nigeria for example has more than 250 ethnic groups; Congo DR has over 400. Economic prosperity that benefits one group at the expense of the others is a recipe for social unrest and political upheaval. Even Somalia which is ethnically homogeneous imploded into chaos and has been without a government since 1991. Second, most of the Asian Tigers are insular. Those unwilling to tolerate authoritarian rule had few options but to stay grin and bear it in the 1970s. By contrast, borders are porous in Africa and those unwilling to live under authoritarian rule will always vote with their feet to go and settle somewhere else. In fact, the continent is crawling with economic and political refugees, as well as those fleeing wars and humanitarian catastrophes. As pointed out earlier, Africans from Egypt, Eritrea, Ethiopia, Gambia and South Sudan were among those who perished in vain attempts to cross the Mediterranean to reach Europe in 2015. Third, several Asian Tigers-Hong Kong, Taiwan and South Korea in particular - faced an external communist threat and, as a result, their people were willing to accept considerable curbs on their civil liberties to fight off that external enemy. Africa has had no such enemy after the 1960s. In fact, for most Africans, the enemy has been within - the state.

"Most African regimes have been so alienated and so violently repressive that their citizens see the state and its development agents as enemies to be evaded, cheated and defeated if possible, but never as partners. The leaders have been so engrossed in coping with the hostilities which their misrule and repression has unleashed that they are unable to take much interest in anything else including the pursuit of development." (Ake, 1991).

Olusegun Obasanjo, former president of Nigeria dismissed Nigeria's National Assembly as "a den of thieves and looters." (Note 17) Of course some of his own colleagues - military dictators such as Gens. Ibrahim Babangida 
and Sani Abacha-turned out to be crackpot democrats and kamikaze bandits, who carted away the entire treasury.

Fourth, and more importantly, Africa needs to devise its own economic development model. For much of the postcolonial period, Africa leaders simply copied many foreign models, systems and paraphernalia, transplanting them into Africa. Virtually every foreign model has some vulgar replica somewhere in Africa. Rome has a Basilica, so one was built in Yamoussoukro, Ivory Coast. France once had an emperor; so in 1975, President Jean-Bedel Bokassa of the Central African Republic spent \$25 million crown himself one. (Note 18) The US has a space center; so Nigeria spent $\$ 89$ million to build the Obasanjo Space Center in 2010 at the time when Nigeria cannot feed itself. The list of such unimaginative copying is endless. The continent is littered with the rancid carcasses of failed imported systems. It would be the height of insanity and irresponsibility to suggest that Africa needs yet another foreign model to copy_-from Singapore. It is probably too late as 38 Confucius Institutes have already been built in 25 African countries so far. (Note 19) Back in 1984, the statues of Marx and Lenin even graced the capitals of Angola, Benin and Ethiopia.

The economic model that Rwanda and other African countries need to copy can be found in Africa itself-in Botswana. It is black Africa's best-kept secret. It has consistently averaged an economic rate of growth above 7\% since the 1980s. Although various analysts have attributed its success to mineral wealth in diamonds, a combination of factors have contributed immensely. Foremost has been the absence of civil war and political strife in its postcolonial history. Second, Botswana enjoys political stability - not wrought by some dictator declaring the country a one-party state. Botswana is a parliamentary democracy. Third, the government has pursued strikingly prudent economic policies, allowing pragmatism, rather than emotional rhetoric, to prevail. It did not squander export windfall from diamonds like Nigeria did of its oil boom. Fourth, Botswana has a lively free press and freedom of expression.

Botswana can find solutions to its economic problems because it permits free debate and freedom of expression. By contrast, much of black Africa is mired in intellectual darkness and economic quagmire, for want of ideas and solutions to extricate itself. Intellectual repression prevents those with ideas from coming forward, even though Article 9 of the African Union's Charter of Human and Peoples' Rights guarantees freedom of expression. As we shall see below, intellectual freedom does not exist in Rwanda either. Fifth, Botswana did not ignore its indigenous roots. It built upon its native system of kgotlas, whereby chiefs and councillors meet "under a tree" to reach a consensus on important matters (Colclough \& McCarthy, 1980). In fact, cabinet ministers are required to attend weekly kgotla meetings. As Fred Dira, an African journalist, explained:

"When they were initiated, kgotla meetings were meant to be totally apolitical. They were to be meetings at which government ministers and members of parliament would brief local communities about official policies and programs, or about issues discussed or to be discussed in parliament. It was also part of the tradition of kgotla meetings that if they were convened by the president or any of his ministers, the respective members of parliament would not only be present, but would also be given some role to play at the meeting. This was in recognition of the fact that at such meetings, MPs shared the role of host with the chiefs." (Note 20)

Of course, Botswana has had its share of problems with income distribution and AIDS. Its diamond deposits may be depleted by 2050. But its economic success demonstrates that Africa does not have to reject its indigenous culture to advance economically. The Japanese did not. "Japan's postwar success has demonstrated that modernization does not mean Westernization. Japan has modernized spectacularly, yet remains utterly different from the West. Economic success in Japan has nothing to do with individualism. It is the fruit of sheer discipline - the ability to work in groups and to conform." (Note 21) This begs question why is Rwanda copying a foreign economic model and not modernizing its own indigenous system, like Botswana?

\subsection{The Lack of Democracy Quotient}

The nexus between democracy and development is rather tenuous. The Asian experience suggests that democracy is not necessary to produce an economic miracle. However, Africa's postcolonial experience suggests ineluctably that democracy is vital to sustain it.

During the Cold War, the World Bank, the IMF and Western donors seldom paid much attention to democracy, focusing only on economic liberalization. It was argued that this was the route the Western countries took - the Industrial Revolution preceded the franchise. If only the leaders in the Third World could tune their economies right, it would unleash powerful forces of change. As people grew richer, a middle-class would emerge that would demand greater say in how to spend their money and how their country is run, which would force political change. This however did not happen in Africa and many parts of the Third World, including China, where 
dictators learned new tricks to beat back the democratic challenge; for example, yanking access to social media at will whenever it suited them.

To be sure, economic liberalization can indeed produce prosperity but all successful economic liberalization under dictatorships eventually hit a political ceiling. This stage is often reached or triggered by a crisis: falling GDP growth rates, increasing unemployment, declining copper prices in Chile in the late 1980s, falling cocoa prices in the case of Ivory Coast in the late 1990s, the Asian financial crisis in the case of Indonesia in 1998, among others. Investors or people who lose money during these crises demand explanations or accountability. When the leadership is "sanguine" enough to flee or open up the political space and address the grievances of the people, the economic prosperity continues without any political tumult. That is, open politics serves as a safety valve that lets off steam. Such was the case in Chile under Augusto Pinochet in the 1980s.

In Africa, however, many of the countries the World Bank restructured into "economic success stories" eventually hit the "political ceiling" but began to unravel when the leadership adamantly refused to open up the political space or introduce democratic reform: Cameroon, Ivory Coast, Ghana, The Gambia, Kenya, Madagascar, Nigeria, Tanzania, Zaire and Zimbabwe. In 1994, for example, the World Bank declared Zimbabwe an "economic success story" but the refusal of the regime of Robert Mugabe to allow democratic governance and accept defeat on a constitutional referendum plunged the country into political turmoil in March 2000 and economic collapse it has not yet recovered from. We discuss two telling cases below.

Ivory Coast is a classic example of economic liberalization without political content. In the 1960s and 1970s, the country enjoyed robust economic growth, averaging 6 percent annually - one of the highest growth rates in Africa-earning accolades from the international community. It was for decades held up as an "economic success story" and a bastion of stability by the World Bank, the IMF and international donors. But its political system was the wretched one-party state. From independence in 1960 to 1993, the country was ruled by the autocratic Felix Houphouet-Boigny. In 1990, following a precipitous drop in world market prices for cocoa - the country's main export — and the collapse of the former Soviet Union, angry protesters demanded political change but the ruling party refused, resorting to political shenanigans and chicanery which plunged the country into civil wars in 2005 and 2010. Ivory Coast is now rebuilding. In 1980, GDP per capita was $\$ 1231.088$; it was $\$ 1398.99$ in 2015, meaning that for 35 years GDP per capita stayed nearly constant, according to World Bank data —an incredibly huge price to pay for lack of democracy. (Note 22)

Madagascar's travails are nearly identical to Ivory Coast's. Gaining independence from France in 1960, its major export was natural vanilla, the world's leading producer. Most of the population subsisted on growing rice and maize. After decades of stagnation under socialist mismanagement, the country's fortunes turned around when its President Didier Ratsiraka undertook serious economic liberalization measures in 1998. Foreign investors were now welcome. Loss-making and non-functioning state-owned enterprises were privatized. The results were specular. Direct foreign investment shot up from nil to \$58.4 million in 1999. The World Bank committed \$629 million into various projects and the EU chipped in $\$ 350$ million for infrastructure development. Exports of textiles to the U.S. soared from $\$ 22$ million in 1998 to $\$ 109$ million in 2000. French companies and tourists returned. But Madagascar's bright prospects were brutally eclipsed by its decrepit political system and bizarre political skulduggery - again, economic liberalization without political reform. For more than a decade-from 2003 to 2013 - attempts to establish a democratic order degenerated into political violence, instability and chaos, which cost the country dearly. In 1980, its GDP per capita was $\$ 462.143$. In 2015; it was $\$ 222.986$, meaning the economic gains made by economic reforms had completely been wiped out, according to World Bank data. (Note 23) Even Rwanda itself offers a more poignant example.

A World Bank mission to the country in December 1993 praised Rwanda's progress on structural adjustment (economic liberalization) and painted a rosy portrait of its future. (Note 24) Its GDP per capita was $\$ 351.278$ in 1990; it sank to $\$ 125.69$ in 1994. (Note 25) Had Rwanda been democratic in 1994, perhaps that dramatic drop in its standard of living would have been averted, not to mention about a million lives saved. As we shall see shortly, the democratic quotient is still missing under Kagame.

\subsection{The Sequence of Reform}

Economic development may be considered as taking a journey from Point A (state of underdevelopment) to Point B (developed state). One needs a driver, a vehicle, road and strategy to travel to one's destination quickly. How fast one gets there would depend upon the skills of the driver, the condition of the vehicle, state of the road and the strategy. Naturally, the "driver" is the head of state. By "vehicle" is meant the ship of state or the state-mobile - the constitution, separation of powers, checks and balances, budgetary management, government policies, dispensation of justice, responsiveness of the government to the needs of the people and the 
effectiveness of other institutions of the state. By "road" is meant infrastructure - clean water supply, electricity, health care, educational system, telecommunications, roads, bridges, and so on. By "strategy" is meant whichever way, ideology, trickery or voodoo incantation it takes to reach the destination quickly — market based or state-controlled strategy?

In most African countries, the development scenario sketched above can be described succinctly as one or more combinations of the following: bad driver, bad vehicle, bad roads, bad strategy and angry passengers fed up with lack of progress. Of course, not all African countries exhibit the same malaise and therefore in need the same prescription. But foreign donors often make the erroneous presumption that "one size fits all," regardless of the nature of the malaise. While some countries may need a new driver, others may need a brake job, a new road or a new strategy. In April 1994, Rwanda's driver, Habyarimana, was dead and his developmentmobile was kaput, requiring a complete overhaul.

Many other African countries faced similar crisis situations. Bad driver because he was often an autocrat and a bandit, having amassed a huge personal fortune by plundering the state treasury. Asked to develop his country, he developed his pocket. (Note 26) The vehicle was often "bad" because the institutions of the state had been debauched or hijacked by the dictator and the ruling elites for self-aggrandizement. Bad roads because of crumpled infrastructure and bad strategy because it was borrowed from abroad, with little affinity to indigenous African culture.

In countries with multiple crises, changing the driver through democratic elections alone was not be enough. A vehicle with no brakes would land in a ditch even if the driver were Nelson Mandela. But this was exactly what happened in many parts in postcolonial Africa. Bad leaders were summarily changed without repairing dilapidated state vehicles. Unwittingly, the international community (Western donors the, IMF, World Bank), instead of helping, often compounded the problem. While one donor was helping rebuild the railway system, another was funding road projects. Worse, there was often little or no coordination among donors. Admittedly, after the collapse of the former Soviet Union in the early 1990s, the situation improved somewhat when donors shifted their focus to fixing various parts of the broken state vehicle but the approach was piecemeal and still with little coordination. While the World Bank was pushing economic reform, various Western governments were advocating democratic reform. The entire reform process in Africa has become a massive glob of confusion.

In reforming postcolonial Africa, three iron-clad lemmas have emerged. First, dictators do not undertake genuine reform and should not be entrusted to do so because in most cases, a conflict of interest situation arises. This point is important because Africa has more dictators per capita than any other continent. These African dictators have brought unspeakable suffering and misery to their people, as well as state collapse. Foreign observers tend to look upon African dictators with benign indifference but this practice needs to stop. There is no such thing as a benevolent dictator in Africa. The only good dictator is a dead one. Dictators do not establish the very institutions that would check their arbitrary use of power. In fact, genuine political reform would require them to commit political suicide. While it might be easier to persuade them to opt for economic reform, we showed in the previous section that economic liberalization without a democratic underpinning may lead to an implosion, as in Ivory Coast and Madagascar.

Second, in post-1994 Rwanda and many African countries, a complete overhaul of the state vehicle was required, not just piecemeal fixes. Third and more important, even if piecemeal reform cannot be avoided, it should not be undertaken haphazardly. For example, a vehicle that has broken down needs to be repaired in a certain order or sequence. One does not install a brand-new carburetor when the spark plugs are fouled up. Nor does one install a brand-new radio when the battery is dead. Similarly, one does not wage war on corruption when judges on the bench are corrupt and the head of state himself is a thief. (Note 27) A broken ship of state or state-mobile must also be reformed in a certain order. For example, free flow of information, private property rights and the rule of law are prerequisites for a free market economy. Institutional reform (for independent and free media as well as independent judiciary) is essential to establish these prerequisites. This means institutional reform must precede free market reform. Unfortunately, these questions have received little attention in the economics literature.

This author believes that the ideal sequence of reform should start with intellectual freedom and then political, constitutional, institutional and economic reforms in that order. (Note 28) Africa's problems must be solved by Africans themselves. For far too long, African leaders sought and relied upon external solutions. (Note 29) But it is Africans who must devise their own internal/African solutions to their problems. More importantly, reform that is internally generated is far more sustainable than reform that is imposed or copied from without. If Africans are dissatisfied with the affairs of the state, they should be able to say so and not wait for the World Bank or external agencies to come and tell them-witness Zimbabwe. They should also be able to throw out of office leaders who 
have failed them, as they do in their traditional system. (Note 30) And more importantly, they should be able to devise a political system that suits their needs and aspirations-political reform. With a newly elected political leadership and team in place, then the flawed constitution, broken institutions and the economic system can be fixed under a more credible leader. Asking the same failed political leader-such as 91-year-old President Robert Mugabe of Zimbabwe - to implement real political reform defies common sense.

All this may sound truculently elementary but intellectual freedom was not a major component of the reform package that was sponsored by Western donors in postcolonial Africa - even in Rwanda after 1994. For decades during the Cold War and up until 1990, Western donors, international aid agencies and multi-lateral development institutions ignored or tolerated despotism, choosing instead to focus solely on the economic liberalization, as we saw above. But dictators do not implement real economic reform; only the type that benefits them and their cronies (crony capitalism). Besides economic liberalization before the other types of reforms makes little sense. When a company goes bankrupt, one does not reorganize it, inject massive infusion of new capital and place it in the hands of the same incompetent managers, who ruined it in the first place. Unfortunately, this was exactly the type of reform protocol the World Bank and Western donors tried to foist on Africa with that sequence of reform. To be sure, after the 1990s, Western donors and the multi-lateral financial institutions began to add "political conditionalities" to their aid programs. For example, in 1991, the World Bank and Western donors withheld aid to Malawi and Kenya until those countries established multi-party democracy. But wily autocrats simply wrote the rules of the game, appointed the Electoral Commissioner, implemented cosmetic changes and held what Africans call "coconut elections" to return themselves to power.

Many experts now agree that economic liberalization and political freedom must go hand in hand. While an improvement, this falls far short of the ideal sequence, discussed above. Economic-cum-political reform is akin to putting the cart before the horse. Real reform begins with intellectual freedom - the most potent liberating force. The incontrovertible proof is supplied by the demise of the former Soviet Union, where intellectual freedom (glasnost) quickly hastened its collapse. It is no wonder that the Chinese communist Politburo is terrified of intellectual freedom and, as we shall see below, so too is President Kagame. In fact, a credible free-market system cannot be built in China or Rwanda i without some intellectual freedom and free flow information. Restricted flow of information triggered the Mexican and Asian financial crisis of the late 1980s and 1990s respectively.

\subsubsection{Rwanda's Case}

It is to the credit of President Paul Kagame that Rwanda exists at all. Outstanding economic achievements have been made but intellectual and political freedoms are seriously lacking. For example, freedom of expression and of thought - the most critical first step in the sequence - are light-years away in Rwanda

Although Article 34 of Rwanda's constitution stipulates that "freedom of the press and freedom of information are recognized and guaranteed by the state," Pres. Paul Kagame brooks no dissent; critics are labeled as enemies and targeted for assassination. In 2013, contract killers were offered \$1million to assassinate two of his most hated enemies. (Note 31) The most-wanted, Patrick Karegeya, was brutally strangled to death in a Johannesburg hotel room on Dec 31, 2013. His killer or killers remain at large. Another target has been Kagame's former army chief, General FaustinKayumbaNyamwasa, who has been the target of a series of attacks and murder plots, which-according to the South African government and other sources-were orchestrated by Rwandan government agents.

Furthermore, the democratic experiment in Rwanda has been farcical. Since 1994, Kagame has won two presidential elections in 2003 and 2010 with more than 90\% of the vote. On Aug 25, 2003 Rwanda held sham elections in which the, President Paul Kagame, won 95 percent of the vote. His main challenger, Faustin Twagiramungu, a former prime minister, secured only 3 percent of the vote. His opposition party, Democratic Republican Movement, was banned. He was vilified in the government-run media, his supporters were harassed, intimidated and jailed.

This farce was repeated in 2010. When Victoire Ingabire returned to Rwanda after six years in exile to form the Unified Democratic Forces (UDF), a coalition of opposition parties, she was immediately arrested and charged with terrorism and endangering the security of the state. She is serving an 8-year jail term. Four high-profile dissidents who formed the Rwanda National Congress in 2010, suffered a similar fate.

The organization's goal was "to bring political change to Rwanda." Kagame denounced its leaders as "terrorists" and cancelled their Rwandan passports. In early 2011, they were tried in a military court in absentia and sentenced to 20 to 24 years of prison on charges of destabilizing public order, endangering state security and fueling ethnic division. Kagame made little secret of his desire to see the RNC leaders dead. "Maybe he deserves it," Mr. Kagame told an interviewer in 2012 when asked about the attempted murder of Gen. Nyamwasa. His 
propaganda newspaper, the New Times, said the RNC leaders should suffer the same fate as Osama bin Laden. (Note 32)

Some of Rwanda's benefactors are expressing strong misgivings:

"The U.S. State Department has already warned the Kagame government that it must not "silence dissidents." It has expressed "deep concern" over Mr. Kagame's public threats against critics and the apparent "politically motivated attacks" on them.

In Britain, police warned two dissidents in 2011 that the Rwandan government "poses an imminent threat to your life." In Sweden, a Rwandan diplomat was expelled in 2012 for "espionage" against Rwandan refugees, and authorities protected an exiled Rwandan newspaper editor who feared for his life. Despite Rwandan officials' denials, the South African government has concluded that the country's diplomats have been involved in murder and attempted murder. In 2010, it recalled its ambassador from Rwanda to protest an attack on a dissident in Johannesburg. And in March (2014), after the latest attack, it expelled four Rwandan diplomats and accused them of "direct links" to the Karegeya assassination and other attempted murders and "organized criminal networks." (Note 33)

\subsection{Miscellaneous Factors}

The behavior of Pres. Kagame in the Great Lakes Region has been even more reprehensible, obliterating any residual sympathy accruing from the 1994 genocide. First he has sponsored three Tutsi-led invasions into Congo DR - a 1997 that was led by the late Laurent-Désiré Kabila to remove the late Mobutu Sese Seko from power. Then in 1998 an invasion to remove Kabila from power. Kabila was assassinated by his security detail in January 2001 and was succeeded by his son, Joseph. And then in 2003, Kagame sponsored M23 Tutsi rebels to remove Joseph Kabila from power. In all, these invasions have claimed the lives of more than 6 million Congolese. Do the lives of 800,000 Tutsis matter more than those of 6 million Congolese?

Second, in April 2001, the UN appointed a Panel of Experts to investigate the illegal exploitation of diamonds, coltan, gold and other resources in the Democratic Republic of Congo (DRC). The Report of the Panel accused Rwanda, Uganda and Zimbabwe and a number of individuals as well as corporations of systematically plundering the mineral resources of the DRC. Rwanda and Uganda, for example, have no known reserves of gold and coltan and yet have been exporting significant quantities of them (UN, 2001; Montague, 2002). (Note 34) The plunder of these mineral resources had fueled conflict In the Great Lakes Region and in response, the US Congress passed the Dodd Frank Act of 2010 to deal with such conflict minerals and prevent anyone from profiting from them. It is difficult for Rwanda to bring genocidaires (those who took part in the genocide) to justice when it violates the laws of Congo DR with impunity.

Finally, the supreme irony is that to avert another genocide President Kagameis unwittingly re-creating the very conditions that led to the 1994 genocide. In order not to raise the specter of genocide, people must not reference their tribal affiliations - Hutu or Tutsi-but must call themselves Rwandans or Rwandese. Any other reference runs afoul of a Constitutional injunction. "Divisionism" is broadly defined as "a crime committed by any oral or written expression or any act of division that could generate conflicts among the population or cause disputes." But it is a blunt, nebulous instrument which has been used by the regime to crack down on dissent. Critics are often denounced as being "divisive" - a charge that can attract a jail term. It may be recalled that Victoire Ingabire, a Hutu, languishes in jail on such a charge.

Even more insidious and dangerous, de facto apartheid reigns unchecked. Nearly all the institutions in Rwanda are controlled by the RPF, which is Tutsi-dominated. In 2004, Kagame instituted the "Girinka" program called "one cow per one family" to cut extreme poverty and improve health and nutrition in rural areas. The logic was simple: give a poor family a cow and it will have milk to drink and manure with which to fertilize its farm. This program has generally been acclaimed to have been successful in reducing rural poverty. But a closer look at the beneficiaries reveals that they are mostly Tutsi. They are pastoralists, who measure their wealth in cattle; the Hutu are peasant farmers. It is difficult to escape the view that the main beneficiaries of Rwanda's economic miracle have been Tutsi, the minority ethnic group - a situation where one form of tribal apartheid by Hutu has been replaced by another type of tribal apartheid by the Tutsi, which is clearly untenable. Even more ominously, political events in Burundi do not bode well for Rwanda.

As was stated earlier, events in Rwanda should not be analyzed in isolation to those of its sister country Burundi. In April 2015, Burundi's President Pierre Nkurunziza, a Hutu, held a shambolic constitutional referendum to allow a run for a third term. It may be recalled that in ungainly steps toward its first multiparty elections, Burundi's Hutu civilian president, Meldior Ndadaye, was killed within three months after being sworn in as president in 1993. His death triggered a horrific tribal massacre that claimed over 100,000 lives and sent more 
than 500,000 refugees streaming into Rwanda, Tanzania, and Zaire. His death also provoked Hutu extremists in Rwanda to act.

The late Nelson Mandela, former president of South Africa, helped broker a peace deal that created a transitional government headed by Pierre Nkurunziza in 2005. At the end of the transition in 2010, his party National Council for the Defense of Democracy - Forces for the Defense of Democracy (CNDD-FDD) won the elections and he stayed on as president on June 2010. With elections looming in July 2015, Nkurunziza argued that he was entitled to a second term because the first five years when he served as head of the transitional government (2005-2010) did not count as a first term since he had not stood for an election. Violent protests ensued which were brutally squashed. Naturally, the referendum "approved" a third term and he won the presidential election in July 2015. However, sustained violent protests left more than 400 people dead and over 500,000sought refuge in Rwanda and neighboring countries. Although divisions did not fall strictly along ethnic lines, the vast majority of the refugees were Tutsi-too reminiscent of the 1994 genocide.

Rwanda's relations with Burundi have deteriorated dramatically. On March 6, 2017, Burundi boycotted the opening ceremony of the East African Legislative Assembly (EALA) in Kigali, Rwanda's capital. Five lawmakers from Burundi's ruling party, CNDD-FDD failed to attend, claiming "they feared for their security." (Note 35)

Kagame's second 7-year term would expire in August 2017. The Constitution debarred him from a third term but a constitutional referendum in December 2015 allowed him to do so- too eerily similar to Burundi's. And this is what the World Bank (2016) wrote:

"Rwanda has maintained political stability since 1994. The last parliamentary elections held in September 2013 saw 64\% of the seats taken by female candidates, and the Rwandan Patriotic Front maintain absolute majority in the Chamber of Deputies. President Paul Kagame is serving his second and last term, and presidential elections are due in 2017. However, in December 2015, the Rwandan constitution was amended and allows the president to run for a third seven year term in 2017. Kagame has since confirmed he will stand for re-election."

As we complained earlier, the international community may think it is helping Rwanda when it is in fact aiding and abetting another implosion. Faced with violent attacks in South Africa and repression at home, Rwandan dissidents see little hope for peaceful change through the ballot box, where Kagame wins more than 90 per cent of the vote of all elections.

"Some of the RNC leaders have hinted that an armed revolt or coup, led by the Rwandan army, might be the only way to depose him. It would be "self-defense," they argue. "If you imprison people and force them into exile, the anger could end up in war again," Gen. Nyamwasa says. (Note 36)

The prospect of an armed revolt is unsettling and frightening. But it may well be inevitable if all the avenues for peaceful change are blocked by Kagame. That eventuality would cause not only unnecessary loss of lives but also of the economic gains that have painstakingly been achieved, as well as the wastage of all that Western aid that went to underwrite it. As was pointed out above, economic liberalization without a democracy quotient is a recipe for implosion.

\section{Conclusion}

The Rwandan story is a trenchant saga of indefatigable courage but misplaced sympathies and petulant fears. Having emerged from calamitous massacre that claimed over 800,000 lives - mostly of the Tutsi ethnic group - in which the international community did nothing to stop, Rwanda under the leadership of its president, Paul Kagame, has clawed its way out of the abyss of Armageddon and made spectacular progress averaging $8 \%$ rate of economic growth since 2001. It is also one of the few African countries that was able to achieve the Millennium Development Goals (MDGs) of halving extreme poverty by 2015. It has the highest percentage of parliamentarians - 64\% - represented by women. However, impressive though Rwanda's economic achievements have been, they are not sustainable.

First, the economic recovery has been fueled by large infusions of Western aid and is vulnerable to any future reductions. Rwanda cannot depend on such large amounts of aid forever and as the World Bank noted, the prospects for Internal generation of private investment funds are rather limited.

Second, the economic model Kagame employed is not one the rest of Africa should emulate however palatable it might be with large dollops of Western aid. This was the Asian Tiger model or that of the late leader of Singapore, Lee Kwan Yew-a model of economic development under authoritarianism or economic liberalization before political reform. 
The Asian Tiger model is unsuitable for Africa and cannot be expected to work there because the circumstances and conditions of the two continents are vastly different. Even then, the historical record is not kind to the application of that model. No dictator - civilian, military nor paramilitary — has brought lasting prosperity to any African country in the postcolonial period. Kagame may be a brilliant tactician but the odds are definitely against him. The enduring economic success stories in Africa-Botswana and Mauritius-are democratic, not authoritarian.

Third, it is true democracy is not necessary to engineer an economic miracle as China and the Asian Tiger model eloquently attest. However Africa's own postcolonial experience emphatically instructs that economic liberalization alone without a democracy quotient is a trip to nowhere as Ivory Coast and Madagascar found in 2000 and 2003 respectively. This should be a caution against blindly copying foreign models. Rwanda under Kagame is not a democratic country but a de facto one-party state. It would be a mammoth tragedy if all that which has been achieved unravels as happened in Ivory Coast and Madagascar.

Fourth, economic liberalization is only one set of reforms needed to move Rwanda to a free society. The others are intellectual freedom, political reform, constitutional reform and institutional reform. The emphasis on economic liberalization upsets the applecart, throwing the entire reform process out of synch-like putting the cart before the horse. Most pernicious has been the lack of freedom of expression. Intolerance of alternative viewpoint is one thing but to seek to assassinate those with such viewpoints reeks of Idi Amin barbarism.

Fifth, political events in Burundi and Uganda do not augur well for Rwanda. In Burundi, President Nkurunziza, a Hutu, organized as sham constitutional referendum to sanction a run for a third term in July 2015. In neighboring Uganda, President Museveni, a Tutsi, who trained and funded Kagame's invasion into Rwanda in 1994 to stop the genocide, won elections for a sixth term in February 2017. Back in 1986, Museveni declared that "No African head of state should be in power for more than 10 years." Thirty-one years later, he is still president. These developments may weigh heavily on Kagame but it would be a grievous mistake if he succumbs to such temptations.

More importantly, Kagame has not helped his own cause with his reckless misadventures in Congo DR. The three invasions he sponsored into that country claimed the lives of more than 6 million Congolese, not to mention engaging in the plunder of the mineral wealth of the Congo.

Given this incontrovertible and overwhelming evidence, it is difficult to end this paper on an optimistic note. It can be argued that without Kagame, Rwanda has no future. But then, that very argument implies that what he has achieved is not sustainable because if it were sustainable, it should endure without him. Kagame won't live forever to ensure that the streets are clean and a business friendly environment prevails. Rwandans should place their faith, not in leaders but rather in institutions. The leadership model has failed Africa terribly. Since 1960, there has been about 230 African heads of state; fewer than 20 were good leaders, developing their economies —not their pockets - and putting their nations' interests above their own. The vast majority, then, failed their people. Why take such a risk in Rwanda?

Leaders come and go but institutions endure. Rwandans should invest in these institutions. An independent electoral commission, independent judiciary, independent and free media, among others, were missing in pre-1994 Rwanda under Habyarimana. Tragically, they are still missing in post-1994 Rwanda under Kagame. In March 2009, when former Pres. Barack Obama addressed Ghana's Parliament, he said this, "Africa does not need strong men; it needs strong institutions."

Given the ethnic composition of the country-85\% Hutu and 15\% Tutsi-democracy may not be a viable option since the Tutsi would be overwhelmed in any election. Such fears are real given what happened in 1994. But one does not replace one form tribal apartheid with another form. Perhaps a new democratic constitution may be adopted that gives the Tutsi real constitutional guarantees and protection, as well as veto power over legislative decisions that discriminate against them. Or another Parliamentary Chamber may be created with equal representation not based on population size but just the three groups-for example, 10 delegates for each ethnic group, with 25 needed to veto a legislation. Failing that, ethnic partitioning of Rwanda and Burundi may be considered as a last resort. The Tutsi may be shepherded into Rwanda and the Hutu into Burundi-just as India and Pakistan were split off in 1947.

\section{References}

Ake, C. (1991). How politics underdevelops Africa. In A. Adedeji, O. Teriba, \& P. Bugembe (Eds.), The Challenge of African Economic Recovery and Development. Portland, OR: Cass. 
Ayittey, G. B. N. (2015). Post-Millennium development goals (MDGs) and Africa's development conundrum. Journal of International Development, 345-361. https://doi.org/10.1002/jid.3086

Ayittey, G. B. N. (2011). Defeating dictators. New York NY: Palgrave/MacMillan.

Ansoms, A. (2005). Resurrection after civil war and genocide: Growth, poverty and inequality in post-conflict "Rwanda". The European Journal of Development Research, 17(3), 495-508. https://doi.org/10.1080/09578810500209577

Colclough, C., \& McCarthy, S. (1980). The political economy of Botswana (p. 298). Oxford: Oxford University Press.

Crisafulli, P., \& Redmond, A. (2012). Rwanda, Inc.: how a devastated nation became an economic model for the developing countries. New York, NY: Palgrave/MacMillan.

Melvern, L. (2013). A People betrayed. London: ZED Books.

Montague, D. (2002). "Stolen goods: Coltan and conflict in the Democratic Republic of Congo. School of Advanced International Studies Review. https://doi.org/10.1353/sais.2002.0016

Republic of Rwanda: Vision 2020 [Revised 2012] Government of Rwanda. Kigale: Government Printer.

United Nations. (1998). Report to the Security Council by Secretary-General. Retrieved from http://www.un.org/en/ga/search/view_doc.asp?symbol=S/1998/333

United Nations. (2001). The Expert Panel Reports on the illegal exploitation of natural resources and other forms of wealth in the Democratic Republic of Congo. http://www.un.org/press/en/2003/sc7642.doc.htm

United Nations. (2012). Report to the Security Council by Secretary-General: Demanding end to support for M23 rebels. Retrieved from http://www.securitycouncilreport.org/atf/cf/\%7B65BFCF9B-6D27-4E9C-8CD3-CF6E4FF96FF9\%7D/s_20 12_843.pdf

UNDP, 2011. Rwanda: Assessment of development results. Retrieved from http://web.undp.org/evaluation/documents/ADR/ADR_Reports/Rwanda/ch3-ADR_Rwanda.pdf

World Bank. (2016). Rwanda overview. Retrieved from http://www.worldbank.org/en/country/rwanda/overview

World Bank. (2015). Rwanda economic update-financing development.

World Economic Forum. (2016). 5 Things to know about Rwanda's economy. Retrieved from https://www.weforum.org/agenda/2016/04/5-things-to-know-about-rwanda-s-economy/

\section{Notes}

Note 1 . Even then, it is important to note that elections alone do not make a country democratic. In addition to periodic elections, the following are also needed:

1) A free and independent press - for free flow of information to inform the public,

2) An independent judiciary — for the rule of law, adjudication of disputes,

3) An independent Electoral Commission — for free, transparent and fair elections,

4) Neutral and professional security forces, and possibly,

5) An independent central bank

If these additional criteria are applied, fewer than five of the African countries would be democratic.

Note 2. Apart from Syrians and Afghans, many of the refugees seeking entry into Europe were from such African countries as Eritrea, Ethiopia, Gambia, Libya, Nigeria, Sudan, among others.

Note 3. A third ethnic group, the Twa, constitute less than $1 \%$ of the population in both countries.

Note 4. An excellent historical account can be found in Melvern (2013)

Note 5. The New York Times. July 25, 1994, p. 7.

Note 6. "At first the killing wasn't purely ethnic. It was also political," said Desire Habiyambire, a Hutu moderate who fled Rwanda with his three children "after his name was circulated on a hit list" (Time, 1994, p. 58). "I am caught in the middle," he added. "Extremism is my enemy. If I meet a Hutu extremist, he will kill me. If I meet a Tutsi extremist, he too will kill me." 
Note 7. "Everyone is fighting against his own brother," said Philippe Gaillard, chief of the Rwanda office of the International Committee of the Red Cross (The Washington Post, 1994, A1).

Note 8. More positive assessments can also be found in Anisoms (2005) and Crisafulli and Redmond (2012).

Note 9. See East African. January 7, 2017.

Note 10. Beside macroeconomic disequilibria, there have been other chinks in Rwanda's armor. Serious allegations of poor planning have been leveled in connection with a $\$ 35$ million biofuel project that was abandoned (See the East African, Feb 12, 2017. Retrieved from http://www.theeastafrican.co.ke/Rwanda/News/Rwanda-abandons-USD35m-biodiesel-pilot-project-/1433218-38 08420-10c5hl7/index.html). Kagame sacked his Minister of Health, Dr Agnès Binagwaho, whose five-year tenure was riddled with scandals. Under her watch, a resurgence of malaria was blamed on government procurement of 3 million substandard mosquito nets which cost the country more than \$15 million in 2013 (East African, July 12, 2016. $\quad$ Retrieved from http://www.theeastafrican.co.ke/news/President-Kagame-fires-Health-Minister/-/2558/3291296/-/format/sitemap /-/mtnfdlz/-/index.html). And Kagame himself is alleged to have amassed a $\$ 500$ million personal fortune (Great Lakes Post December 6, 2015. Retrieved from http://glpost.com/paul-kagame-net-worth-500-million/).

Note 11. There have also been allegations of falsification of data. "Rwandan authorities manipulated the latest official statistics on poverty to make it look like it was going down, while much of the source data suggested it was actually on the increase. Poverty "actually rose by six percent", according to information obtained by FRANCE 24 and Belgian university Professor Filip Reyntjens," France24 Nov 2, 2015 (Retrieved from http://www.france24.com/en/20151102-rwanda-accused-manipulating-poverty-statistics)

Note 12. That horrible tragedy was encapsulated in the movie, Black Hawk Down.

Note 13. Following the defeat of Nazism, the Convention on Genocide was the world's first human rights treaty and if the UN was founded with one aim, it was to prevent such calamities. This also explained why the US response to the humanitarian crisis in Darfur, Sudan in 2003 was also tepid.

Note 14. An indictment of President Clinton and U.S. officials is provided by Melvern (2013)

Note 15. Here is the link to his speech posted by the White House. Retrieved from http://www.cbsnews.com/news/text-of-clintons-rwanda-speech/

Note $16 . \quad$ Morning Edition. $\quad$ (Retrieved http://www.npr.org/2012/09/17/161222794/rwandan-economy-makes-unlikely-climb-in-rank)

Note 17. See Premiere Times, Josh, Nov 24, 2014.

Note 18. It did not help any. He was overthrown in a coup and chased out of the country 1979. Successive military regimes were no better, plunging the country into civil war, pitting Christians against Muslims beginning in 2012. So total has been the devastation that the country must be rebuilt from scratch, meaning 50 years of independence have been wasted.

Note 19. A posting at this website claims that there are 60 such institutes and classrooms across Africa. Retrieved http://theconversation.com/chinas-confucius-institutes-arent-perfect-but-have-much-to-offer-africa-51596

from

Note 20. See Mmegi/The Reporter, May 12-18, 1995, p. 7.

Note 21. See, Editorial in the Bangkok Post quoted. In The Washington Times, Nov 9, 1996, p. A8.

Note 22. See http://data.worldbank.org/indicator/NY.GDP.PCAP.CD?locations=CI

Note 23. This was posted at http://data.worldbank.org/indicator/NY.GDP.PCAP.CD?locations=MG

Note 24. This author read the incredulous report. After the April 1994 genocide, it would have been too embarrassing for the World Bank to have the report remain in circulation. So it was quietly and hurriedly recalled from circulation, redacted, sanitized and rereleased in May 1994. A tell tale sign of this skulduggery is the fact that the date on the official World Bank document is handwritten with a felt pen, which may be seen at this site http://documents.worldbank.org/curated/en/711471468765285964/pdf/multi0page.pdf.

Note 25. World Bank. Retrieved from http://data.worldbank.org/indicator/NY.GDP.PCAP.CD?locations=RW

Note 26. The Forbes magazine published on Nov 8, 2011 a list of Africa's richest dictators. Retrieved from https://www.forbes.com/sites/mfonobongnsehe/2011/11/08/who-were-africas-richest-dictators/\#73eae9617086 
Note 27. There have been too many such cases in Africa. In Feb 2014 when Lamidu Sanusi, the former governor of the Central Bank of Nigeria, reported that some $\$ 20$ billion in oil revenue was missing, it was he, the governor, who was immediately sacked by ex-Pres. Goodluck Jonathan for financial recklessness and misconduct! ( $B B C$ News, Feb 20, 2014). In Zimbabwe, the anti-corruption czar, Ngonidzashe Gumbo, was himself a bandit, jailed for 10 years for defrauding the commission of $\$ 435,000$ (The Herald, March 3, 2015). Elsewhere, the bodies set up to fight corruption in Kenya and Tanzania were themselves also corrupt.

Note 28. A detailed discussion of this sequence can be found in Ayittey, 2011; Chapter 8. To be provocative, force debate and invite challenges, this author called it "Ayittey's Law" for those working from the inside. Real reform begins with intellectual freedom. It may seem trite to professionals in advanced countries but extremely important to those working in developing countries or Africa. If this sequence is botched, a revolution may be reversed - as was the Arab Spring in Egypt in 2015-and it may take a generation for another opportunity to correct it. Benin got it to right in 1991 when it established as sovereign national conference to find solutions and transition from a Marxist dictatorship to a democratic society. The delegates were free to exercise their intellectual freedom to debate the solutions. South Africa followed with the Convention for a Democratic South Africa (CODESA), also in 1991. Similarly in Ghana in 1996. Those African countries that began their reform regimen with intellectual freedom experienced the least violent transition from dictatorship to democracy Benin, South Africa, Cape Verde Islands, Ghana, South Africa, Tanzania, Tunisia, Zambia, among others. By contrast, Libya where intellectual freedom was most restricted, the transition was most violent, leading to the destruction of the country. Many blame the West and NATO for this destruction but Gadhafi could have saved Libya had he been willing to relinquish or share political power. Why didn't he after 41 years in power?

Note 29. It was for this reason why this author coined the expression "African solutions for African problems" in 1994. An African solution however is not just one crafted by an African leader but one that is anchored in African heritage.

Note 30. Such was the case of Nana Sobin Kan II, the Chief of Asansi-Dompuase traditional area in the Ashanti region of Ghana. He was deposed on Feb 7, 2012 for "continuously showing gross disrespect and disregard to kingmakers and elders of the stool. He had continuously sown seeds of confusion and litigation in the traditional area through the rampant sale of stool lands to private developers without plot numbers and site plans. He was also accused of having received huge sums of money as compensation on behalf of the Adansi-Dompuase traditional areas from AngloGold Ashanti last year but failed to disclose the amount involved to kingmakers." (Daily Guide, Feb 10, 2012, p. 17).

Note 31. In a riveting report, reporters of The Globe \&Mail, Judi Rever and Geoffrey York, described how the assassination plot is hatched in excruciating detail-Assassination in Africa: Inside the plots to kill Rwanda's dissidents," The Globe \& Mail (Nov 5, 2015). They wrote, "Rwandan exiles in both South Africa and Belgium gave detailed accounts of being recruited to assassinate critics of President Kagame. Their evidence is the strongest yet to support what human rights groups and Rwandan exiles have suspected for years about the Rwandan government's involvement in attacks or planned attacks on dissidents, not only in South Africa but in Britain, Sweden, Belgium, Uganda, Kenya and Mozambique."

Note 32. See The Globe and Mail, Nov 5, 2015.

Note 33. See The Globe and Mail, Nov 5, 2015.

Note 34. Congo DR sued Rwanda and Uganda at the International Court of Justice (ICJ) for reparations. In 2005 ", the Court ordered Uganda to pay damages, reckoning that $\$ 6-\$ 10$ billion would be sufficient. (The Guardian, Dec. 20, 2005). But Uganda counter-sued, claiming damage to its embassy in Kinshasa. They were given up to September 2015 to resolve their cases against each other but by December 2015, had not done so.

Note 35. The five legislators from Burundi who were absent were MsEmerenceBucumi, Ms Isabelle Ndahayo, Mr Jean Marie Muhirwa, Mr Emmanuel Nengo and MrLeonceNd because these arubagiye (The Citizen, March 7 2017).

Note 36. See The Globe and Mail, Nov 5, 2015.

\section{Copyrights}

Copyright for this article is retained by the author(s), with first publication rights granted to the journal.

This is an open-access article distributed under the terms and conditions of the Creative Commons Attribution license (http://creativecommons.org/licenses/by/4.0/). 